To cite this article: Olayemi A. Nwogbe \& Yacob Haliso (2020) Continuing Professional Development Assessment of Healthcare Professionals in Public Secondary Hospitals in Lagos State, Nigeria. Information Impact: Journal of Information and Knowledge Management, 11:1, 25-39, DOI: dx.doi.org/10.4314/iijikm.v11i1.3

To link to this article: https://doi.org/10.4314/iijikm.v11i1.3

\title{
Continuing Professional Development Assessment of Healthcare Professionals in Public Secondary Hospitals in Lagos State, Nigeria
}

\author{
${ }^{1}$ Olayemi A. Nwogbe and ${ }^{1}$ Yacob Haliso \\ ${ }^{1}$ Department of Information Resources Management Babcock University, Ilisan-Remo, Ogun State
}

\begin{abstract}
This study investigates the engagement of healthcare professionals in continuing professional development in public secondary hospitals in Lagos State, Nigeria. A survey research design and a multistage sampling technique were adopted for the study. The sample consisted of 356 healthcare professionals (112 physicians, 32 pharmacists and 212 nurses). The data were collected using a self-developed structured questionnaire. The questions were built based on the literature review with modified questions adapted from widely used the questionnaires on hospital survey on patient safety, ambulatory and community pharmacy, nursing safety practices and CPD professional and skill competency and World Health Organization Regional Guidelines for Continuing Medical Education. Healthcare professionals in adult general outpatient departments were only included in the study. Findings revealed that physicians engagement in informal CPD (conferences, seminars, in-service training) is $(M=3.09)$, and formal CPD (conduct of research, publications or peer journal review) $(M=$ 2.11). Pharmacists engagement in informal CPD is $(M=3.10)$ and formal CPD $(M=1.89)$, Nurses' engagement in informal CPD is $(M$ $=2.30)$ and CPD $(M=1.78)$. These evidence indicates that the respondents tend to lean more on less time-demanding and workbased capacity building approach, than they engaged mostly in informal CPD activities than they engaged in a methodical educational and professional advanced method of capacity building. The study recommends improved Government funding for training, policy improvement on organizational support and working conditions for study leave opportunities, and aligning the metrics of evaluating and scoring CPD engagement with the need assessment gaps in healthcare system in renewing practicing license of healthcare professionals.
\end{abstract}

Keywords Capacity building, Healthcare professionals

Public healthcare service, Health workers training

CONTACT Olayemi A. Nwogbe \& Yacob Haliso layemimails1@yahoo.com Department of Information Resources Management, Babcock University, llisan-Remo, Ogun State, Nigeria

2020 The Authors Published with License by Information Impact

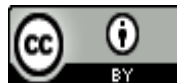




\section{Introduction}

Continuing professional development (CPD) is considered as crucial to the medical career development. CPD involves learning or training activities directed at building professional competence and confidence of healthcare professionals to perform their duties effectively (Filipe, Silva, Stulting, \& Golnik, 2014). Basically, continuing professional development improves professional expertise and scholastic capability for clinical and teaching responsibilities of healthcare professionals throughout their working life. The concept of continuing professional development therefore involves the building of newer competencies and at the same time, expanding and strengthening already acquired knowledge and skills. In other words, healthcare professionals constitute a critically important component of a successful healthcare delivery system (World Health Organization, 2013). Therefore, CPD is widely accepted as a standard method of training and retraining healthcare professionals to maximize their potentials for best practice. Expectedly, patients rely greatly on healthcare professionals, trusting them with their lives and expecting to always get safe care. Undoubtedly, every patient has a right to quality care devoid of threat to their lives. As such, healthcare professionals have an obligation to keep improving on their capabilities to provide quality and safe care. It is important that healthcare professionals take advantage of CPD training opportunities to improve on their knowledge and skills and maintain quality improvement in patient care. Hence, prevent incidences of errors or mistakes that may predispose patients to harm or injury (American Nurses Association, 2015). As it is in every profession, the medical science and practice is very dynamic and entails continuing learning to gain contemporary knowledge throughout medical career life. Invariably, healthcare professionals need advanced trainings to gain current knowledge of practices and methods in medical care. A competent health workforce is critical to the delivery of quality and safe healthcare and maintaining excellent public health (Institute of Medicine, 2010). According to World Health Organization (2016), successful delivery of quality and safe health service is determined by having the right quantity and quality mix of healthcare professionals in hospitals. World Health Organization (2017) assert that poor training of healthcare professionals contributes significantly to the deplorable state of healthcare delivery globally and especially in developing countries like Nigeria. It is needful to emphasize that healthcare professional's should develop individual professional development plan (PDP). Subsequently, they need to develop personal continuing professional plan. CPD plan should be anchored on predetermined PDP that is attainable. The personal CPD plan should be based on training objectives of PDP in line with identified knowledge and skill gaps. Equally, CPD plan must be structured and goal driven to build desired capacity. Overall, CPD plan should identify training needs, objectives, timeline, specific training identified, training evaluation technique, and documentation of CPD. In essence, CPD constitute the channel through which targets set by professional development plan is achieved (Cottrell, 2010).

Potentially, hospitals are safety haven where pain, distress, anxiety, fear, vulnerability, chronic and life-threatening conditions of people can be eased through quality and safe care. Clearly, no hospital can be readily poised to provide excellent healthcare delivery without competent human resources. The ability of health organizations or hospitals to provide desirable healthcare services is greatly influenced by well-trained health workforce. Arinze-Onyia, Ndu, Aguwa, Modebe and Nwamoh (2018) reported that poor healthcare delivery in public hospitals in Nigeria could be associated with incompetency. Several other evidences from literature also linked incompetence of healthcare professionals to harmful incidences relating to anesthesia overdose, injection injury, infected blood transfusion, wrong diagnosis and treatment, administration of counterfeit drugs and adverse drug reactions, poor surgical procedures in hospitals (Jones, \& Kely, 2014; Nwosu, 2015; Acheampong, Tetteh, \& Anto, 2016; Ajala, 2017; Muhammad, Abdulkareem \& Chowdhury, 2017; Mekonnen, Alhawassi, McLachlan, \& Brien, 2018). Reportedly, the magnitude of harm occurring in hospitals is alarming and over one-third of such harms is preventable to a greater degree (Illingworth, 2015). According to the World Health Organization (2013), 
mistakes or errors are attributable to inadequate knowledge and skills of healthcare professionals in hospitals. Tsang (2013) assert that medical errors responsible for patient harm could be avoided with sound training to enhance the knowledge and skills of caregivers. Government and hospitals have the responsibilities to protect the health of the populace by ensuring the delivery of high-quality healthcare. This is achievable through a well-motivated, planned, implemented and sustained training programed for health workers.

In Nigeria, secondary public hospitals are commonly referred to as general hospitals. The Secondary public hospitals have jurisdiction to operate within specific local government areas. Lagos State is listed as second in the country with the highest number secondary public hospitals. Secondary hospitals in Lagos State receive a daily influx of people from across the country seeking quality healthcare services. There are more government owned public hospitals than privately owned hospitals (67\% vs. 33\%) (Makinde, Sule, Ayankogbe, \& Boone, 2019). In effect, public hospitals are responsible for managing the health of the majority of Nigerians. Yet, evidence from literature indicates a shortage of skilled healthcare professionals in public hospitals due to poor human resource management planning, and under-funding of the public health system (Adeloye, David, Olaogun, \& Auta, 2017). Furthermore, it is reported that 60 to $90 \%$ of patients who bypass secondary hospitals to seek care in tertiary health hospital by self-refer, allegedly do so based on poor knowledge and skills of healthcare professionals in secondary hospitals (Okoli, Obembe, Osungbade, Adeniji, \& Adewole, 2017; Koce, Randhawa, \& Ochieng, 2019). Therefore, capacity building of healthcare professionals at all levels of healthcare delivery is key to effectively multiplying the health gains of the country's population (Lee, Chen, Chien, Pelikan, Wang, \& Chu, 2015). It is often alleged that implementation and execution of policies by Nigerian government is derailed by political and economic setbacks. United Nations Development Programme (2019), classified Nigeria as a "low human development" country, with a ranking of 158th out of 189 countries assessed worldwide. This poor rating reflects the evident neglect in human capacity development in the Nigerian healthcare system. Poor health system policy implementation, low funding, unmet knowledge and skills development needs contributes majorly to the poor and unsafe healthcare delivery in Nigeria (World Health Organization, 2016). Despite the challenges in health human resource development in Nigeria, capacity building of healthcare professionals particularly in public hospitals has not been extensively studied. Hence, this is study assessed the engagement of healthcare professionals in continuing professional development in public secondary hospitals in Lagos State, Nigeria.

\section{Objective of the study}

The objective of this study is to investigate the engagement of healthcare professionals in continuing professional development in public secondary hospitals in Lagos, Nigeria. The specific objectives of the study were to:

1. to examine the frequency of engagement in continuing professional development among healthcare professionals in public secondary hospitals in Lagos, Nigeria;

2. assess continuing professional development engagements of healthcare professionals in public secondary hospitals in Lagos, Nigeria.

\section{Research questions}

1. What is the frequency of engagement in continuing professional development activities among healthcare professionals in public secondary hospitals in Lagos, Nigeria?

2. What are the continuing professional development engagements of healthcare professionals in public secondary hospitals in Lagos Nigeria? 


\section{Literature review}

Collin, van der Heijden, and Lewis (2012), define continuing professional development as a training process which takes place in workplaces and organizations for career growth and organizational performance. All forms of post basic professional and educational trainings of healthcare professionals are regarded as CPD. Continuing professional development provide indispensable professional lifelong learning opportunities. It also presents a common ground for healthcare professionals to build capabilities that valuable in delivering patient care efficiently. World Health Organization (2013) asserts that education and training of healthcare professionals is strategic in optimizing patient care. Wheeler and Chisholm-Burns (2018) contend that healthcare CPD must planned, systematic, and contextual to job responsibilities of healthcare professionals. Daniel-Ebune and Joda (2017) opined that it is obligatory for healthcare professionals to should engage in CPD to keep abreast of advancements in medical practice and ensure that patient derive maximum benefits from healthcare delivery service. The World Federation for Medical Education (2003) classified continuing professional development as formal and informal learning or training activities. These activities consist of work-based learning and trainings related to advance educational degrees, medical fellowship education, and other forms of self-directed learning tasks. Informal CPD activities are less structured, but interactive learning or training activities such as inservice-training, short refresher courses, hands-on-practical, coaching of trainees, and work shadowing (observing a professional to gain insights and experience) (Nasreen \& Odhiambo, 2018). Other informal CPD activities include conferences, seminars and workshops, general reading, updating knowledge via the internet, and voluntary involvement in a community or public service. Informal CPD also involved participating in activities of professional bodies or learned societies. On the other hand, formal CPD involves teaching and lecturing, mentoring or being an examiner, or assessor. It also involves acquiring postgraduate training, residency programs, or MSc, or PhD degrees. Other CPD formal activities include conducting research, writing research papers, books, and reviewing journal articles (Khan, 2010; Health Education England, 2018). CPD activities are usually measured and verified according to professional relevance and certificates of attendance by professionals associations before granting or renewing practicing license. Oyemakinde, Nguku, Babirye, Gitta, Nsubuga, and Nyager (2014) asserted that healthcare professionals should regularly engage in in-service-training, short refresher courses, hands-onpractical, conferences, seminars, workshops and coaching to gain more insights and experience on the job. Soeiro, and Rangel (2016) maintained that CPD activities such as lecturing, research, papers and books writing, and medical residency, $\mathrm{MSc}, \mathrm{PhD}$ are all innovative educational activities with high scholastic impacts on professionalism and job performance.

Informal CPD, is a less structured form of learning that can be integrated as on-the-job training. Informal CPD focus more on strengthening interactive and participatory professional knowledge sharing among healthcare professionals. While formal CPD consisting of advanced educational and professional methodical, in-depth and rigorous scientific and research learning process, it is important for healthcare professionals to combine both informal and formal forms of CPD in developing their knowledge and skills. In addition, Feldacker, Pintye, Jacob, Chung, Middleton, and Iliffe, et al. (2017) assert that healthcare professionals may engage in continuing professional development either through conventional traditional classroom learning or independent online learning. Physicians, pharmacists and nurses can also engage in self-paced e-Learning via web-based online courses, self-directed distance learning modules, webinars, or teleconferencing sessions. Elearning method has tremendously aided various forms of distance learning. Feldacker et al. (2017) reported that healthcare professionals preferred online CPD learning. In addition, there are several CPD learning models structured to address different learning and training needs. These models are designed to impact medical and non-medical competencies related to professionalism, and interpersonal, managerial and communication skill. The three most common models of CPD are; 
i. Update models aim to communicate or disseminate information.

ii. Competence models aim to ensure that minimum standards for knowledge, skills and attitudes are attained.

iii. Performance models aim to help healthcare professionals overcome barriers to successful changes in practice and help them resolve clinical concerns (Anshu \& Singh, 2017, p. 19).

Continuing professional development is no doubt complementary to the graduate and postgraduate education of healthcare professionals (Khan, 2010). CPD is mandated by various medical examinations and professional licensing bodies in major countries of the world (Grant, 2012). CPD combines a holistic method of enhancing knowledge and skills for high performance in clinical practice (Khan, 2010). Unarguably, engaging in continuing professional development will essentially transform the mindset, knowledge, behavior and capabilities of healthcare professionals. CPD bridges the gaps between medical knowledge and practice by helping healthcare professionals keep pace with current knowledge and standard methods in patient care. CPD either face-to-face by human interaction or technologically aided through electronic presentation platforms offers novel ideas and problem-solving skills in medical practice. CDP contribute to proliferating cutting-edge knowledge and techniques valuable to provide quality and safe patient care (Filipe, Silva, Stulting, \& Golnik, 2014). Premeditatedly, CPD models are designed to develop actual and potential intellectual prowess of healthcare professionals. In addition, CPD creates the platform for cross-fertilization of ideas and experiences that can improve performance and increase positive health outcomes. Continuing professional development is therefore a critical component of several other interventions that may be deployed to strengthen healthcare delivery service in any country (World Health Organization, 2016). Viljoen (2013) emphasized that engagement in CPD activities will improve learning and address gaps in professional practice. However, Kitto, Bell, Peller, Sargeant, Etchells and Reeves et al. (2013) observed a lack of interest and low participation of healthcare professionals in CPD due to poor motivation, finance, and poor working conditions.

It is the responsibility of individual healthcare professionals to engage in CPD; while, medical professional bodies in each country handle the regulation. The planning, implementation and regulation of CPD differs in different countries. There is legal enforcement of CPD compliance in some countries while others do not have it. In Africa, high emphasis is laid on continuing professional development in several countries, but policies and legal frameworks to support it are at varying levels of evolving into legal acts. In Malawi, for example, the CPD is mandatory for healthcare professionals including nurses and midwives. In Tanzania, the planning, implementation and evaluation of CPD is driven by grant /financial donor agencies alongside the government (Feldacker, Pintye, Jacob, Chung, Middleton, \& Iliffe 2017). Continuing professional development is considered important for healthcare professionals in Egypt, however, lack of regulating system for license renewal is less motivating for CPD engagement in the country. Physicians in Egypt therefore prefer to pursue international medical certifications due to its wide acceptance as an alternative to Ph.D. degrees for non-academic physicians (Nassar, 2017). Jordan passed a bylaw in 2018 mandating all physicians to engage in continuing professional development for knowledge and competency upgrade and the prerequisite for renewal practicing license every 5 years (Younes, AbuAlRub, Alshraideh, Abu-Helalah, Alhamss, \& Qanno', 2019). As far back as 2004, the East African Countries of Uganda, Kenya and Tanzania jointly agreed at a consultation meeting to develop resources and policies to make CPD mandatory for re-certification of practicing licenses in the East African region. In these countries currently, healthcare professionals are mandated to accumulate certain credits points in CPD before applying for license renewal (Ndege, 2006). In Rwanda, it is mandatory for healthcare professionals to provide evidence of credit points earned from CPD activities before licenses renewal. The Nigerian the legal framework to regulate CPD was strengthened in 2012, and as such, healthcare professionals are mandated to engage in CPD. Medical and Dental Council of Nigeria for example expect that doctors should have acquired at least 20 CPD credit units in the preceding year before eligibility for annual renewal of practicing licenses (Medical and Dental Council of 
Nigeria, 2011). Similarly, the Nursing and Midwifery Council of Nigeria in 2010, mandated CPD for nurses to keep them abreast of modern trends in nursing practice (Ingwu, Efekalam, Nwaneri, Ohaeri, Ogbonnaya, \& Chikeme, 2019). The Pharmacists Council of Nigeria also mandated CPD for recertification of pharmacist's practicing license in Nigeria (Pharmacists Council of Nigeria, 2013). In Nigeria, lack of motivation and incentives from employers, heavy clinical workload, financial constraints and lack of information about CPD programs have been identified as some of the factors constituting hindrances to CPD engagements among healthcare professionals (Ilesanmi, \& Famolu, 2016).

In the United States, healthcare professionals are mandated to engage in continuing education all through their career lives. It is a measure to maintain current professionally knowledge that will translate into sound medical practice (Institute of Medicine (US), (2010). Also among the European Union (EU) member states, 17 of the member states mandates CPD for certain cadres of health workers. The remaining 10 countries established guidelines to encourage participation in CPD (Costa, Van Hemelryck, Aparicio, Gatzemeier, Leer, \& Maillet et al., 2010). The United Kingdom mandated registered medical practitioners to engage in CPD (General Medical Council, 2012). In Latin America, medical professional associations provide accreditation for CPD and specialty certifications based on a compulsory accumulation of CPD credit point units. Similarly, private hospitals in Latin America mandate healthcare professionals in their employment to engage in CPD courses (Pelletier, 2010). The Association of Southeast Asia Nations (ASEAN) countries promulgated 'Law on Examination and Treatment' (LET) to regulate issuance of licenses to physicians, nurses, midwives, and assistant doctors based on accumulation of CPD points (van der Velden, Hun Nguyen, Vu Quoc Yuy, Van Huu, \& Robert, 2010). In Southwest Asia, the United Arab Emirates require for an annual license renewal mandate physicians to acquire nothing less than 50 hours of CPD, of which 25 must be in formal education obtained from an accredited medical school or a professional body (Hassan, Berham, \& Smith, 2010). Singapore mandates physicians to engage in CPD to renew their licenses (van der Velden et al. 2010). Japan has no mandatory system for CPD, but the medical association conducts voluntary certification for his members Japan, and up to $70 \%$ of its membership are certified (Pelletier 2010).

\section{Methodology}

This study adopted a survey research design. The study population is 1025 healthcare professionals (physicians, pharmacists and nurses) in public secondary hospitals in Lagos State, Nigeria. There are twenty (20) public hospitals across fifteen (15) (LGAs) in the three (3) senatorial districts (Lagos Central, Lagos East and Lagos West) in the state. Yamane (1970) sample size determination formula was adopted to calculate sample of 356 consist of 112 physicians, 32 pharmacists and 212 nurses drawn from general outpatient departments (GOPD) of ten (10) public secondary hospitals. A multistage sampling technique was adopted. In the first stage, a purposive sampling technique was used to select fifteen (15) Local Government Areas with public secondary hospitals. In the second stage, a systematic selection of ten (10) public secondary hospitals from a total of twenty (20) hospitals was carried out. In the third stage, the sample size of the healthcare professionals were proportionately selected from the known population per hospital, and lastly, a convenient selection of the respondents were done in each hospital. The questionnaire was developed based on adapted and modified questions from CPD professional and skill competency characteristics developed by American Board of Medical Specialties (2012). A total of 351 questionnaires (107 physicians, 32 pharmacists and 212 nurses) were returned and analyzed from 356 distributed, given a response rate of 98.6\%. Data collected were analyzed using descriptive statistics. Ethical approval was obtained from the Babcock University Health Research Ethics Committee and the Lagos State Health Service Commission. 


\section{Results}

Table 1. Demographic characteristics of healthcare professionals

\begin{tabular}{|c|c|c|c|}
\hline \multirow[t]{2}{*}{ Variables } & $\begin{array}{c}\text { Physicians } \\
n=107\end{array}$ & $\begin{array}{c}\text { Pharmacists } \\
\mathrm{n}=32\end{array}$ & $\begin{array}{l}\text { Nurses } \\
n=212\end{array}$ \\
\hline & Frequency (\%) & Frequency (\%) & Frequency (\%) \\
\hline \multicolumn{4}{|l|}{ Age } \\
\hline $18-34 y r s$ & $22(20.6)$ & $13(40.6)$ & $35(16.5)$ \\
\hline $36-45 y r s$ & $73(68.2)$ & $18(56.3)$ & $161(75.9)$ \\
\hline $46-55 y r s$ & $10(9.3)$ & $1(3.1)$ & $16(7.5)$ \\
\hline$>55 y r s$ & $2(1.9)$ & - & - \\
\hline \multicolumn{4}{|l|}{ Gender } \\
\hline Male & $60(56.1)$ & $5(15.6)$ & $13(6.1)$ \\
\hline Female & 47 (43.9) & $27(84.4)$ & $199(93.9)$ \\
\hline \multicolumn{4}{|l|}{ Marital Status } \\
\hline Single & $20(18.7)$ & $6(18.8)$ & $11(5.2)$ \\
\hline Married & $86(80.4)$ & $26(81.3)$ & $201(94.8)$ \\
\hline Separated & $1(1.9)$ & - & - \\
\hline \multicolumn{4}{|l|}{ Highest level of Education } \\
\hline $\mathrm{RN}$ & - & - & $37(17.5)$ \\
\hline $\mathrm{RN} / \mathrm{RM}$ & - & - & $132(62.3)$ \\
\hline MBBS / B. Pharm / BNSc & $97(90.7)$ & $18(56.3)$ & $43(20.3)$ \\
\hline MSc/ M. Pharm & - & $8(25.0)$ & - \\
\hline $\mathrm{PhD}$ & - & $6(18.8)$ & - \\
\hline Fellowship & $10(9.3)$ & - & - \\
\hline \multicolumn{4}{|l|}{ Length of Practice } \\
\hline $1-5 y r s$ & $21(19.6)$ & $9(28.1)$ & $17(8.0)$ \\
\hline $6-10 y r s$ & $26(24.3)$ & $13(40.6)$ & $59(27.8)$ \\
\hline $11-15 y r s$ & $36(33.6)$ & $6(18.8)$ & $60(28.30$ \\
\hline $16-20 y r s$ & $19(17.8)$ & $3(9.4)$ & $35(16.5)$ \\
\hline$>20 y r s$ & $5(4.7)$ & $1(3.1)$ & $41(19.3)$ \\
\hline \multicolumn{4}{|l|}{ Department/ Unit } \\
\hline Pharmacy & - & 23 (71.9) & - \\
\hline GOPD & $48(44.9)$ & $9(28.1)$ & $94(44.3)$ \\
\hline$O \& G$ & 47 (43.9) & - & $48(22.6)$ \\
\hline Ophthalmology & $5(4.7)$ & - & - \\
\hline Oncology & $2(1.9)$ & - & - \\
\hline HCT/ARV Clinic & $3(2.8)$ & - & $3(1.4)$ \\
\hline General Surgery & - & - & $4(1.9)$ \\
\hline Internal Medicine & $2(1.9)$ & - & $30(14.2)$ \\
\hline Physiotherapy & - & - & $12(5.7)$ \\
\hline Gastroenterology & - & - & $17(8.0)$ \\
\hline Infectious Diseases & & - & $4(1.9)$ \\
\hline
\end{tabular}

The demographic characteristics of healthcare professionals (physicians, pharmacists and nurses) are summarized in Table 1 above. The majority, $68.2 \%$ of physicians, $56.3 \%$ of pharmacists and $75.9 \%$ of nurses are aged 36-45 years. In terms of gender, $56.1 \%$ of physicians are male and female $43.9 \%$. The male pharmacists are $15.6 \%$ and females $84.4 \%$. Nurses are $6.1 \%$ male and majority, $93.9 \%$ female. Pharmacists and nurses were majorly females, $84.4 \%$ and $93.9 \%$ respectively. Physicians married are $80.4 \%$, singles $18.7 \%$ and separated $1.9 \%$. Pharmacists married, $81.3 \%$ and $8.8 \%$ are single. Nurses married are $94.8 \%$ and $5.2 \%$ single. In terms of educational level, the majority, $91.7 \%$ of the physician's practice with basic MBBS degree and $9.3 \%$ had a fellowship degree. Pharmacists with basic B. Pharm qualifications are 56.3\%, M. Pharm, 25.0\% and fellowship degree $18.8 \%$. Majority of the nurses, $62.3 \%$ are trained mid-wives, RN/RM qualifications, $20.3 \%$ and BNSc degree $17.5 \%$. Physicians, $31.1 \%$ had worked for between 11-15yrs and 26.2\% for 6-10yrs. Pharmacists who have worked between 6-11yrs are $40.6 \%$ and $28.1 \%$ 11-15yrs. Nurses, $28.3 \%$ had worked for 11-15yrs, and $27.8 \%$ for 6- 
10yrs. Furthermore, physicians sampled were from general outpatient departments (GOPD), 45.9\%, obstetrics and gynaecology, 39.3\%, oncology $4.7 \%$, internal medicine $1.9 \%$, ophthalmology, $4.7 \%$ and HIV/AIDS $2.8 \%$. Pharmacists were sampled from the pharmacy department, $71.9 \%$ and GOPD $28.1 \%$. Nurses sampled were from GOPD, $44.3 \%$, obstetrics and gynaecology, $22.6 \%$ and internal medicine, $14.4 \%$.

Research question 1: What is the frequency of engagement in continuing professional development activities among healthcare professionals in public secondary hospitals secondary hospitals in Lagos State, Nigeria?

Table 2 Frequency of engagement in CPD among Healthcare Professionals

\begin{tabular}{lccc}
\hline Items & $\begin{array}{c}\text { Physicians } \\
\mathbf{n = 1 0 7}\end{array}$ & $\begin{array}{c}\text { Pharmacists } \\
\mathbf{n = 3 2}\end{array}$ & $\begin{array}{c}\text { Nurses } \\
\mathbf{n}=\mathbf{2 1 2}\end{array}$ \\
\hline $\begin{array}{l}\text { How often do you engage in CPD } \\
\text { activities? }\end{array}$ & & & \\
Never & $8(3.8)$ & - & $2(1.9)$ \\
Monthly & $11(5.2)$ & - & $6(5.6)$ \\
Bimonthly & - & $4(12.5)$ & $7(6.5)$ \\
Quarterly & $34(16.0)$ & $6(18.8)$ & $48(44.9)$ \\
Every 6 months & $39(18.4)$ & $17(53.1$ & $22(20.6)$ \\
Annually & $46(21.7)$ & $5(15.6)$ & $12(11.2)$ \\
No fixed schedule & $74(34.9)$ & - & $10(9.3)$ \\
& & & \\
\hline Source: Survey (2019) & & & \\
\hline
\end{tabular}

Table 2 shows that a significant number of the physicians, $34.9 \%$ had no fixed schedule for engaging in CPD. Physicians, $21.7 \%$ engaged in CPD annually, $18.4 \%$, every 6 months, and quarterly, $16.0 \%$. Data also reveal that $5.2 \%$ of physicians monthly engage in CPD activities, while $3.8 \%$ have never engaged in CPD. The majority of the nurses, $44.9 \%$ engage in CPD quarterly, $20.6 \% 6$ monthly, $11.2 \%$ annually, 9.3\% no fixed schedule time plan for engaging in CPD, 6.5\% engaged bi-monthly, 5.6\% monthly and $1.9 \%$ never. Most pharmacists, $53.1 \%$ engage in CDP every 6 months, $18.8 \%$ quarterly, $15.6 \%$ annually, and $12.5 \%$ bi-monthly.

Research question 2: What are the continuing professional development engagements of healthcare professionals in public secondary hospitals in Southwest, Nigeria?

Table 3: $\quad$ CPD engagement of physicians

\begin{tabular}{|c|c|c|c|c|c|c|}
\hline $\begin{array}{l}\text { Variables } \\
(n=107)\end{array}$ & $\begin{array}{l}\text { Often } \\
\text { Freq. (\%) }\end{array}$ & $\begin{array}{c}\text { Sometimes } \\
\text { Freq. } \\
(\%)\end{array}$ & $\begin{array}{l}\text { Rarely } \\
\text { Freq. (\%) }\end{array}$ & $\begin{array}{l}\text { Never } \\
\text { Freq. (\%) }\end{array}$ & Mean & SD \\
\hline \multicolumn{7}{|l|}{ Informal CPD } \\
\hline $\begin{array}{l}\text { I participate in in-house-trainings hands- } \\
\text { on-practical }\end{array}$ & $46(43.0)$ & $35(32.7)$ & $17(15.9)$ & $9(8.4)$ & 3.10 & .961 \\
\hline I engage in short professional courses & $22(20.6)$ & $54(50.5)$ & $28(26.2)$ & $3(2.8)$ & 2.89 & .756 \\
\hline $\begin{array}{l}\text { I attend conferences, seminars, } \\
\text { workshops, meeting }\end{array}$ & $32(29.9)$ & $60(56.1)$ & $15(14.0)$ & - & 3.16 & .646 \\
\hline $\begin{array}{l}\text { I give presentations at meetings, } \\
\text { conferences, seminars, workshops }\end{array}$ & $16(15.0)$ & $49(45.8)$ & $31(29.0)$ & $11(10.3)$ & 2.65 & .859 \\
\hline $\begin{array}{l}\text { I engage in general reading, leaning / } \\
\text { gathering of medical knowledge }\end{array}$ & $74(69.2)$ & $31(29.0)$ & $2(1.9)$ & - & 3.67 & .510 \\
\hline Average weighted mean & & & & & 3.09 & \\
\hline Average weighted SD & & & & & & .746 \\
\hline \multicolumn{7}{|l|}{ Formal CPD } \\
\hline $\begin{array}{l}\text { I engage in research and paper } \\
\text { publication }\end{array}$ & $8(7.5)$ & $21(19.6)$ & $60(56.1)$ & $18(16.8)$ & 2.18 & .799 \\
\hline $\begin{array}{l}\text { I engage in peer review of bio-medical } \\
\text { publication }\end{array}$ & $6(5.6)$ & $19(17.8)$ & $43(40.2)$ & $39(36.4)$ & 1.93 & .876 \\
\hline
\end{tabular}




\begin{tabular}{llccccc}
\hline I author / books / reports / manuals & $4(3.7)$ & $10(9.3)$ & $25(23.4)$ & $68(63.6)$ & 1.53 & .816 \\
\hline I lecture / teach professional courses & $8(7.5)$ & $21(19.6)$ & $30(28.0)$ & $48(44.9)$ & 1.90 & .971 \\
\hline $\begin{array}{l}\text { I coach or mentor (such as providing } \\
\begin{array}{l}\text { instruction, and guidance) to trainees or } \\
\text { students }\end{array}\end{array}$ & $30(28.0)$ & $43(40.2)$ & $25(23.4)$ & $9(8.4)$ & 2.88 & .918 \\
\hline $\begin{array}{l}\text { I conduct professional technical } \\
\text { assessment of medical practice }\end{array}$ & $17(15.9)$ & $21(19.6)$ & $36(33.6)$ & $33(30.8)$ & 2.21 & 1.053 \\
\hline
\end{tabular}

Table 3 showed that $43.0 \%$ of physicians often engaged in in-house practical hands-on training, $50.5 \%$ sometimes engaged in short professional courses, and $56.1 \%$ sometimes engaged conferences, seminars, workshops, meeting. Physicians, 56.1\% rarely engaged in research and paper publications, $40.2 \%$ rarely engaged in peer review of bio-medical publications, $63.6 \%$ never engaged in the authorship of books, reports or manuals. Physicians, 44.9\% never engaged in lecturing or teaching professional courses. Physicians who engaged in general reading, leaning or gathering medical knowledge were $69.2 \%$ and $40.2 \%$ sometimes coach or mentor trainees or students. Physicians, $33.6 \%$ rarely engaged in professional technical assessment of medical practice. Overall, physicians engagement in informal CPD $(M=3.09)$ and formal CPD $(M=2.11)$.

Table 4: $\quad$ CPD engagement of pharmacists

\begin{tabular}{|c|c|c|c|c|c|c|}
\hline $\begin{array}{l}\text { Variables } \\
(\mathrm{N}=32)\end{array}$ & $\begin{array}{l}\text { Often } \\
\text { Freq. } \\
(\%)\end{array}$ & $\begin{array}{l}\text { Sometimes } \\
\text { Freq. (\%) }\end{array}$ & $\begin{array}{l}\text { Rarely } \\
\text { Freq. (\%) }\end{array}$ & $\begin{array}{c}\text { Never } \\
\text { Freq. (\%) }\end{array}$ & Mean & SD \\
\hline \multicolumn{7}{|l|}{ Informal CPD } \\
\hline $\begin{array}{l}\text { I participate in in-house-trainings } \\
\text { hands-on-practical }\end{array}$ & $12(37.5)$ & $15(46.9)$ & $2(6.3)$ & $2(6.3)$ & 3.19 & .833 \\
\hline $\begin{array}{l}\text { I engage in short professional } \\
\text { courses }\end{array}$ & $9(28.1)$ & $14(43.8)$ & $6(18.8)$ & $2(6.3)$ & 2.97 & .875 \\
\hline $\begin{array}{l}\text { I attend conferences, seminars, } \\
\text { workshops, meeting }\end{array}$ & $14(43.8)$ & $13(40.6)$ & $4(12.5)$ & - & 3.32 & .702 \\
\hline $\begin{array}{l}\text { give presentations at meetings, } \\
\text { conferences, seminars, } \\
\text { workshops }\end{array}$ & $7(21.9)$ & $14(43.8)$ & $2(6.3)$ & $8(25.8)$ & 2.65 & 1.112 \\
\hline $\begin{array}{l}\text { I engage in general reading, } \\
\text { leaning / gathering of medical } \\
\text { knowledge }\end{array}$ & $15(46.9)$ & $12(37.5)$ & $4(12.5)$ & - & 3.35 & .709 \\
\hline Average weighted mean & & & & & 3.10 & \\
\hline Average weighted SD & & & & & & .846 \\
\hline \multicolumn{7}{|l|}{ Formal CPD } \\
\hline $\begin{array}{l}\text { I engage in research and paper } \\
\text { publication }\end{array}$ & $2(6.3)$ & $1(34.4)$ & $10(31.3)$ & $8(25.0)$ & 2.23 & .920 \\
\hline $\begin{array}{l}\text { I engage in peer review of bio- } \\
\text { medical publication }\end{array}$ & $1(3.1)$ & $6(18.8)$ & $7(21.9)$ & $17(53.1)$ & 1.71 & .920 \\
\hline $\begin{array}{l}\text { I author / books / reports / } \\
\text { manuals }\end{array}$ & $1(3.1)$ & $3(9.4)$ & $1(3.1)$ & $26(81.3)$ & 1.32 & .791 \\
\hline $\begin{array}{l}\text { I lecture / teach professional } \\
\text { courses }\end{array}$ & $2(6.3)$ & $4(12.5)$ & $2(6.3)$ & $23(71.9)$ & 1.52 & .962 \\
\hline $\begin{array}{l}\text { I coach or mentor (such as } \\
\text { providing instruction, and } \\
\text { guidance) to trainees or students }\end{array}$ & $7(21.9)$ & $9(28.1)$ & $9(28.1)$ & $6(18.8)$ & 2.55 & 1.060 \\
\hline $\begin{array}{l}\text { I conduct professional technical } \\
\text { assessment of pharmacy practice }\end{array}$ & $4(12.5)$ & $6(18.8)$ & $7(21.9)$ & $14(43.8)$ & 2.00 & 1.095 \\
\hline Average weighted mean & & & & & 1.89 & \\
\hline Average weighted SD & & & & & & 0.958 \\
\hline
\end{tabular}


In Table 4, Pharmacists, $46.9 \%$ sometimes engaged in in-house-trainings or hands-on-practical, while $43.8 \%$ sometimes engaged in short professional courses, $40.6 \%$ sometimes engaged in conferences, seminars, workshops and meetings. Pharmacists, $43.8 \%$ sometimes give presentations at meetings, conferences, seminars, workshops, and $34.4 \%$ sometimes engaged in research and paper publications. As high as $53.1 \%$ never engaged in peer review of bio-medical publications, $81.3 \%$ never authored books, reports or manuals, $71.9 \%$ never engaged in lecturing or teaching professional courses, $21.9 \%$ often coach or mentor trainees or students, and $43.8 \%$ never conducted professional technical assessment of pharmacy practice. Pharmacists sometimes engage in informal CPD $(M=3.10)$ and formal CPD $(M=$ 1.89).

Table 5 CPD engagements of nurses

\begin{tabular}{|c|c|c|c|c|c|c|}
\hline Variables & $\begin{array}{c}\text { Often } \\
\text { Freq. (\%) }\end{array}$ & $\begin{array}{l}\text { Sometimes } \\
\text { Freq. (\%) }\end{array}$ & $\begin{array}{l}\text { Rarely } \\
\text { Freq. (\%) }\end{array}$ & $\begin{array}{l}\text { Never } \\
\text { Freq. (\%) }\end{array}$ & Mean & SD \\
\hline \multicolumn{7}{|l|}{ Informal CPD } \\
\hline $\begin{array}{l}\text { I participate in in-house-trainings } \\
\text { hands-on-practical }\end{array}$ & $44(20.8)$ & $44(20.8)$ & $38(17.9)$ & $84(39.6)$ & 2.23 & 1.184 \\
\hline I engage in short professional courses & $27(12.7)$ & 66 (31.1) & $57(26.9)$ & $60(28.3)$ & 2.29 & 1.019 \\
\hline $\begin{array}{l}\text { I attend conferences, seminars, } \\
\text { workshops, meeting }\end{array}$ & $33(15.6)$ & $90(45.5)$ & $66(31.1)$ & $19(9.0)$ & 2.66 & .853 \\
\hline $\begin{array}{l}\text { I give presentations at meetings, } \\
\text { conferences, seminars, workshops }\end{array}$ & $7(21.9)$ & $14(43.8)$ & $2(6.3)$ & $8(25.8)$ & 1.87 & 1.074 \\
\hline $\begin{array}{l}\text { I engage in general reading, leaning / } \\
\text { gathering of medical knowledge }\end{array}$ & $53(25.0)$ & $69(32.5)$ & $15(7.1)$ & $75(35.4)$ & 2.47 & 1.210 \\
\hline Average weighted mean & & & & & 2.30 & \\
\hline Average weighted SD & & & & & & 1.068 \\
\hline \multicolumn{7}{|l|}{ Formal CPD } \\
\hline $\begin{array}{l}\text { I engage in research and paper } \\
\text { publications }\end{array}$ & $8(8.3)$ & $21(9.9)$ & $39(18.4)$ & $144(67.9)$ & 1.50 & .823 \\
\hline $\begin{array}{l}\text { I engage in peer review of bio-medical } \\
\text { publication }\end{array}$ & $7(3.3)$ & $19(9.0)$ & $37(17.5)$ & $149(53.1)$ & 1.45 & .793 \\
\hline I author / books / reports / manuals & $17(8.0)$ & $14(6.6)$ & $32(15.1)$ & $135(63.7)$ & 1.48 & .931 \\
\hline I lecture / teach professional courses & $15(7.1)$ & $30(14.2)$ & $2(6.3)$ & $23(71.9)$ & 1.65 & .970 \\
\hline $\begin{array}{l}\text { l coach or mentor (such as providing } \\
\text { instruction, and guidance) to trainees } \\
\text { or students }\end{array}$ & $67(31.6)$ & $42(19.8)$ & $13(6.1)$ & $90(42.5)$ & 2.41 & 1.315 \\
\hline $\begin{array}{l}\text { I conduct professional technical } \\
\text { assessment of nursing practice }\end{array}$ & $49(23.1)$ & $37(17.5)$ & $26(12.3)$ & $100(47.2)$ & 2.17 & 1.245 \\
\hline Average weighted mean & & & & & 1.78 & \\
\hline Average weighted SD & & & & & & 1.013 \\
\hline
\end{tabular}

Table 5 data reveals that only $20.8 \%$ of the nurses often engaged in in-house training or hands-onpractical to build their capacity. Nurses, $31.1 \%$ sometimes engaged in short professional courses and a significant number, $45.5 \%$ sometimes attend conferences, seminars, workshops and meetings. Nurses, $43.8 \%$ sometimes give presentations at meetings, conferences, seminars, and workshops. Majoritiy, $67.9 \%$ of nurses have never been engaged in research and paper publications; $53.1 \%$ have never engaged in peer review of bio-medical publications; $63.7 \%$ have never authored books or manuals. A significant percent, $71.9 \%$ of nurses have never lectured or teach professional courses. Nurses who sometimes indulge in general reading, leaning or gathering of medical knowledge are 32.5\%, 31.6\% of the nurses often coach or mentor trainees or students, however, $47.2 \%$ have never been engaged in conducting professional technical assessment of nursing practice. Overall, nurses sometimes engage in informal CPD $(M=2.30)$ and formal CPD $(M=1.79)$. 


\section{Discussion}

In this study, the engagement of healthcare professionals in continuing professional development (CPD) was measured based on the two classifications of CPD; informal CPD and formal CPD. The findings from the study showed physicians' informal CPD, $(M=3.09)$ and formal CPD $(M=2.11)$; pharmacists' informal CPD, $(M=3.10)$ and formal CPD, $(M=1.89)$, and nurses' informal CPD, $(M=2.30)$ and formal CPD $(M=1.79)$. This result showed that healthcare professionals' engagement in informal CPD generally had the highest mean score value compared to the mean score value for formal CPD. In order words, physicians, pharmacists and nurses are more practically orientated in their learning approach by engaging mostly in informal CPD activities such as seminars, conferences, in-service trainings, or short courses. This finding is in congruence with several current studies depicting healthcare professionals as engaging more in informal CPD learning activities than formal for reasons poor finance and knowledge of CPD programs, or constricted working hours. For example, a study conducted in Egypt by Nassar (2017) found that physicians engaged mostly in reading books and conducting online literature search as a form of CDP. Similarly, Younes, AbuAlRub, Alshraideh, Abu-Helalah, Alhamss, and Qanno' (2019) while examining the engagement of Jordanian physicians in CPD, found that the physicians have a high preference for indulging in professional discussions with their peers during clinical consultations. Likewise, a study on CPD in Kenya by Priscah, Omenge, Robert and Ndwiga (2017) reported that majority, $58.6 \%$ of nurses engaged in conferences, workshops, and seminars and rarely engage in formal CPD such as advance postgraduate studies, professional fellowship training, scientific research and paper publications, journal review, book authorship, lecturing and professional technical assistance. Furthermore, Daniel-Ebune and Joda (2017) similarly reported seminars, workshops and conferences as main trainings activities among pharmacists studied. Correspondingly, a study on impact of nurse workload on CPD by Coventry, Maslin-Prothero, and Smith (2015) reported a poor engagement in formal CPD learning activities among healthcare professionals. Also, in similarity, Schwartz (2012) assert less than $2 \%$ of physicians engage substantially in scientific research to advance clinical practice.

Although CPD is structured as self-directed and practice-based learning activities rather than supervised training, however, emphasis by professional medical associations on CDP activities is for enhancement of both professional and educational development and skill building improve clinical roles, scientific knowledge, team building and leadership, communication, medical ethics, teaching, research and administration (World Federation for Medical Education, 2000). As such, it is essential that healthcare professionals should actively engage in both informal and formal CPD to advance their professional and educational competences necessary to deliver excellent healthcare to the people at all times. Most importantly, CPD engagement of healthcare professionals should be characterized by a clear need assessment based on identified the gaps in clinical practice; the drive to provide optimal care, and the need to preserve job satisfaction. Above all, identification of knowledge gap(s) or need assessment constitute a critical yardstick for choice of suitable CPD activities. Determining need assessment therefore, should involve systematic audit of clinical practice, clinical interventions and event analysis, audit of common mistakes and patient complaints, and feedbacks from inter and intra professional team members in clinical practice (World Federation for Medical Education, 2003).

\section{Conclusion and recommendations}

It is evident from the findings of this study that healthcare professionals in public secondary hospitals engaged more in informal CPD than formal CPD. Also, evidence from literature review suggests that finance and work environment compels healthcare professionals to indulge more in convenient and workbased informal CPD activities than formal. However, formal and informal CPD would suitably enhance 
educational and professional health human development necessary to strengthen healthcare delivery service in any country. The study therefore recommends:

1. Policy improvement on organizational support and working conditions for study leave opportunities in healthcare organizations

2. Increase in government funding on training of healthcare professionals at all levels of healthcare delivery system in the country.

3. Improvement in the metrics of evaluating the relevance of CPD to need assessment gaps in healthcare delivery system and contemporary trends in medical practice while rating CPD points for renewal of practicing licenses.

\section{References}

Acheampong, F., Tetteh, A. R., \& Anto, B. P. (2016). Medication administration errors in an adult emergency department of a tertiary health care facility in Ghana. Journal Patient Saf., 12(4), 223-228.

Adeloye, D., David, R., \& Olaogun, A. Auta, A. (2017). Health workforce and governance:ThecrisisinNigeria. Human Resource Health, 15(32). https://doi.org/10.1186/s12960017-0205-4

Ajala, T. (2017, October 14,) Wrong diagnosis: Nigeria's silent killer. Punch newspaper. Retrieved from http://www.punchng.com/wrong-diagnosis-nigerias-silent-killer/

American Board of Medical Specialties. (2012). Maintenance of Certification Competencies. Retrieved from http://www.abms.org.

American Nurses Association. (2015). Nursing: Scope and Standards of Practice (3rd ed.). Silver Spring, MD: ANA.

Anshu, A. H., \& Singh, T. (2017). Continuing professional development of doctors. The National medical journal of India, 30(2), 89-92

Arinze-Onyia, S. U., Ndu, A. C., Aguwa, E. N., Modebe, I., \& Nwamoh, U. N. (2018).

Knowledge and practice of standard precautions by health-care workers in a tertiary health institution in Enugu, Nigeria. Nigerian Journal of Clinical Practice, 21(2), 149-155.

Collin, K., van der Heijden, B., \& Lewis, P. (2012). Continuing professional development. International Journal of Training and Development, 16(3). Doi: 10.1111/j.14682419.2012.00410.x

Costa, A. F., Van Hemelryck, A., Aparicio, W., Gatzemeier, J. W., Leer, B., \& Maillet, D. K. (2010). "Continuing medical education in Europe: Towards a harmonized system." European Journal of Cancer, 46(13), 2340-2343.

Cottrell, S. (2010) Skills for Success: The Personal Development Planning

Handbook. London: Palgrave Macmillan, (2nd ed.)

http://www.palgrave.com/studyskills/pdp/

Coventry, T. H., Maslin-Prothero, S. E., \& Smith, G. (2015). Organizational impact of nurse supply and workload on nurses continuing professional development opportunities: An integrative review. Journal of Advanced Nursing 71(12). Doi: 10.1111/jan.12724.

Daniel-Ebune, E. O., \& Joda, A. E. (2017). Assessment of continuing professional development activities among pharmacists in Nigeria. West African Journal of Pharmacy, 28 (1), 1. 
Feldacker, C., Pintye, J., Jacob, S., Chung, M. H., Middleton, L., \& Iliffe, J, et al. (2017). Continuing professional development for medical, nursing, and midwifery cadres in Malawi, Tanzania and South Africa: A qualitative evaluation. PLoS ONE, 12(10), e0186074. https://doi.org/10.1371/journal.pone.0186074

Filipe, H. P., Silva, E. D., Stulting, A. A. \& Golnik, K. C (2014). Continuing professional development: Best practices. Middle East Afr Journal Ophthalmol, 21(2), 134-141.

General Medical Council. (2012). Continuing professional development guidance for all doctors. Retrieved from https://www.gmc-uk.org/-/media/documents/cpd-guidance-for-alldoctors-0316_pdf-56438625.pdf

Grant, J. (2012). The good CPD guide. A practical guide to managed continuing professional development in medicine. (2nd ed). London, NY: Radcliffe Publishing.

Hassan, Y., Berham, B. \& Smith. P. C. (2010). "Perceptions of continuing medical education, professional development, and organizational support in the United Arab Emirates." Journal of Continuing Education in the Health Professions 30, no. 4: 251-256.

Health Education England (2018). Establishing common standards for continuing professional development, assessment and appraisal guidelines for medical associate professionals. Retrieved from https://www.hee.nhs.uk/sites/default/files/documents/MAP\%20CPD\%20Assessment\%20and\%20 Appraisal\%20Framework\%20Final\%20FINAL\%20for\%20web.pdf

Ilesanmi, O. A., \& Famolu, B. F. (2016). Role of motivation in enhancing productivity in Nigeria. European Journal of Management, 8(28).

Illingworth, J. (2015). Continuous improvement of patient safety: The case for change in the NHS. London: Health Foundation. Retrieved from https://www.health.org.uk/sites/default/files/ContinuousImprovementPatientSafety.pdf

Ingwu, J., Efekalam, J., Nwaneri, A., Ohaeri, B., Ogbonnaya, C., \& Chikeme, P. (2019). perception towards mandatory continuing professional development programme among nurses working at University of Nigeria Teaching Hospital, Enugu-Nigeria. International Journal of Africa Nursing Sciences. 11.

Doi: 10.1016/j.ijans.2019.100169

Institute of Medicine (US). (2010). Redesigning Continuing Education in the Health Professions. Washington (DC): National Academies Press (US); 2010. Retrieved from https://www.ncbi.nlm.nih.gov/books/NBK219809/

Jones, A., \& Kely, D. (2014). Deafening silence? Time to reconsider whether organizations are silent or deaf when things go wrong. Retrieved from http://qualitysafety. bmj.com.eproxy1.lib.hku.hk/content/23/9/709.full.pdf+html

Khan, A.W. (2010) Continuing Professional Development (CPD): What should we do? Bangladesh Journal of Medical Education (01), 01.

Kitto, S., Bell, M., Peller, J., Sargeant, J., Etchells, E., \& Reeves, H. et al. (2013). Positioning continuing education: boundaries and intersections between the domains continuing education, knowledge translation, patient safety and quality improvement. Advance in Health Science Education, 18. 141-156.

Koce, F., Randhawa, G., \& Ochieng, B. (2019). Understanding healthcare self-referral in Nigeria from the service users' perspective: a qualitative study of Niger state. BMC Health Serv Res, 19, 209. https://doi.org/10.1186/s12913-019-4046-9

Lee, C. B., Chen, M. S., Chien, S., Pelikan, J. M., Wang, Y. W., \& Chu, C. M. (2015. Strengthening health promotion in hospitals with capacity building: a Taiwanese case study, Health Promotion International, 30 (3), 625-636. https://doi.org/10.1093/heapro/dat089 
Makinde, O. A., Sule, A., Ayankogbe, O., \& Boone, D. (2019). Distribution of health facilities in Nigeria: Implications and options for universal health coverage. International Journal of Health Planning and Management. doi: 10.1002/hpm.2603

Medical and Dental Council of Nigeria (2011). CPD at a glance. Retrieved from http://www.mdcnigeria.org/Downloads/CPD\%20AT\%20A\%20GLANCE.pdf

Mekonnen, A. M., Alhawassi, T. M., McLachlan, A. J., \& Brien, J. E. (2018). Adverse Drug Events and Medication Errors in African Hospitals: A Systematic Review Drugs Real World Outcomes, 5(1), 1-24.

Muhammad, F., Abdulkareem, J. H., \& Chowdhury, A. (2017). Major public health problems in Nigeria: A review. South East Asia Journal of Public Health, 7(1), 6-11. doi: http://dx.doi.org/10.3329/seajph.v7i1.34672

Nasreen, A., \& Odhiambo, G. (2018). The continuous professional development of school principals: Current practices in Pakistan. Current Practices in Pakistan, 40

Nassar, M. F. M. A (2017). Continuing Professional Development in the Healthcare Sector in Egypt: A Readiness Assessment. (A thesis submitted to the public policy and administration department in partial fulfillment of the requirements for the degree of Master of Public Administration). Retrieved from https://pdfs.semanticscholar.org/bf62/29e8243da0448191bf71a1374451a8aca032.pdf

Ndege, S. (2006). Continuing professional development: A southern perspective. (International hospital federation reference book 2005/2006). Kenya: Pathfinder International. Retrieved from http://www.ihf-fih.org/en/content/download/213/1361/file/42ndege_jh.pdf

Neimeyer, G. J., Taylor, J. M., Zemansky, M., \& Rothke, S. E. (2013). Do mandates matter? The impact of continuing education mandates on participation in continuing professional development activities. Professional Psychology: Research and Practice, 44(2).

Nwosu, A. (2015). The horror of wrong-site surgery continues: Report of two cases in a regional trauma centre in Nigeria. Patient Safety in Surgery, 9(1), 6.

Okoli, H., Obembe, T., Osungbade, K., Adeniji, F., \& Adewole, (2017). D. Self-referral patterns among federal civil servants in Oyo state, South-Western Nigeria. Pan African Medical Journal, 26, 105.

Oyemakinde, A., Nguku, P., Babirye, R., Gitta, S., Nsubuga, P., \& Nyager, J. (2014). Building a public health workforce in Nigeria through experiential training. Pan African Medical Journal, 18 (1 1), 1.

Pharmacists Council of Nigeria (2013). Mandatory continuing professional development programme (MCPD) programme for the re-certification of the pharmacists in Nigeria. Modules $X, X I, X I I$. (4th Ed.) Abuja: PCN.

Pelletier, S. 2010. "Globalizing CME's future.” Medical Meetings, (37)6, 35-37

Priscah, M., Omenge, O. R., Robert, K., \& Ndwiga, T. (2017). Continuing Professional Development Practices among Nurses in Western Kenya. International Journal of Science and Research Methodology, 7, (1).

Schwartz, D. A. (2012). Physician-Scientists: The bridge between medicine and science. American Journal of Respiratory and Critical Care Medicine, 185.

Soeiro, A., \& Rangel, B. (2016). Innovation in continuing professional development: a vision of the future. Proceedings of the 15th world conference of international association of continuing engineering education. IACEE, Porto - Portuga. www.fe.up.pt/iacee

Tsang, L. (2013) Identify gaps between local and international measures to avoid administration error on 1-year review in United Christian Hospital, Hong Kong. Open Journal of Nursing, 3, 13-20. doi: 10.4236/ojn.2013.38A003. 
United Nations Development Programme (UNDP) 2019. Human Development Report.

Committee on the health professions education summit: Greiner. Retrieved from http://hdr.undp.org/en/content/2019-human-development-index-ranking Institute of Medicine (US)

van der Velden, T., Hun Nguyen, V., Vu Quoc Yuy, N., Van Huu, N., \& Robert, B. (2010).

"Continuing medical education in Vietnam: New legislation and new roles for medical schools." Journal of Continuing Education in the Health Professions 30, no. 2: 144-148

Viljoen, M. E. (2013). Strategies to enhance attendance of a continuous professional development programme for critical care nurse practitioners at a private hospital in Gauteng (A degree thesis). Retrieved from https://www.mobt3ath.com/uplode/book/book-47779.pdf. (Nr 25407733)

Wheeler. J. S, \& Chisholm-Burns, M. (2018). The Benefit of Continuing Professional Development for Continuing Pharmacy Education. American Journal of Pharmaceutical Education, 82(3), 6461. doi: 10.5688/ajpe6461.

World Federation for Medical Education. (2000). Task force on defining international standards in basic medical education. Report of the Working Party, Medical Education, 34, 665-675.

World Federation for Medical Education (2003). Continuing professional development of medical physicians: WFME global standards for quality improvement. Retrieved from http://www.wfme.org/standards/cpd/doc_download/16-continuingprofessional-development-cpd-ofmedicalphysicians--english.

World Health Organization (2013). Transforming and scaling up health professionals' education and training: World Health Organization Guidelines.

Retrieved from https://whoeducationguidelines.org/.../whoeduguidelines_PolicyBrief_Financing.pdf

World Health Organization (2016). Global strategy on human resources for health: Workforce 2030. Geneva: WHO.

World Health Organization (2017). Patient Safety: Making health care safer. Retrieved from WHO/HIS/SDS/2017.11.

Yamane, T. (1973) Statistics: An introductory analysis. 3rd Edition, Harper and ... doi: 10.4236/ajcm.2017.71002

Younes, N. A., AbuAlRub, R., Alshraideh, H., Abu-Helalah, M. A., Alhamss, S., \& Qanno', O (2019). Engagement of Jordanian Physicians in Continuous Professional Development: Current Practices, Motivation, and Barriers. International Journal of General Medicine, 12, 475-483. doi https://doi.org/10.2147/IJGM.S232248 